\title{
COMPARATIVE EFFECTS OF CLOMIPRAMINE AND DULOXETINE ON DETRUSOR AND STRIATED SPHINCTER FUNCTION IN MALE AND FEMALE RABBITS.
}

\author{
Francisco Carlos Pérez Martínez', Remigio Vela Navarrete' and Carlos Castilla Reparaz². \\ 'Departamento de Urología, Universidad Autónoma de Madrid. Fundación Jiménez Díaz. Madrid. \\ ${ }^{2}$ Departamento de Cirugía Experimental y Experimentación Animal. Fundación Jiménez Díaz. Madrid. Spain.
}

\begin{abstract}
Summary.- OBJECTIVE: Serotonin and norepinephrine systems are involved in the neural control of lower urinary tract function. The aim of this study was to compare the response on striated anal sphincter electromyographic (SAS-EMG) activity and cystometric parameters, when duloxetine and clomipramine were intravenously administrated.
\end{abstract}

METHODS: The effects of intravenous 1 and $2 \mathrm{mg} . / \mathrm{Kg}$. duloxetine or clomipramine on lower urinary tract function were studied in a total of 32 male and 32 female rabbits, under nonirritative conditions (intravesical infusion of saline) and in a model of bladder irritation (i.e., transvesical infusion of $0.5 \%$ acetic acid). A transurethral double-lumen catheter in male rabbits, and a subcutaneous cystostomy in female rabbits, were used for liquid infusion and recording of intravesical pressure during a cystometrogram. Simultaneously, SAS-EMG was recorded through electromyography electrodes placed in the perianal striated muscle.

RESULTS: Cystometric parameters: Under irritative conditions, $2 \mathrm{mg} . / \mathrm{Kg}$. clomipramine in male rabbits and 1 or $2 \mathrm{mg} . / \mathrm{Kg}$. in female rabbits, depending on the dose, increased bladder capacity (BC), contraction duration $(C D)$ and intercontraction interval (ICI), and decreased baseline pressure (BP). In male and female rabbits, duloxetine dose-dependently increased BC, CD and ICl. Under nonirritative conditions, clomipramine at $2 \mathrm{mg}$./ $\mathrm{Kg}$. and duloxetine dose-dependently solely increased $B C$ in female rabbits. Electromyographic activity: A marked effect on SAS-EMG activity of duloxetine under irritative conditions was revealed in male and female rabbits. Under these conditions, clomipramine increased SAS-EMG activity only in female rabbits. Under nonirritative conditions, $2 \mathrm{mg} . / \mathrm{Kg}$. duloxetine increased SASEMG activity only in female rabbits.

CONCLUSIONS: The stronger effects on the SAS-EMG activity were produced by duloxetine in female rabbits under irritated bladder conditions. Clomipramine, under irritative conditions, had a relaxing effect on intravesical pressure, which is not the case with duloxetine.

Keywords: Urinary incontinence. Clomipramine. Duloxetine. Lower urinary tract.

Resumen.- OBJETIVO: Neurotransmisores como la serotonina y la norepinefrina están involucrados en el control neural del tracto urinario inferior. El objetivo de este trabajo consistió en comparar los efectos de duloxetina y clomipramina sobre parámetros cistométricos y la actividad electromiográfica del esfínter anal estriado (SAS-EMG). 
MÉTODOS: Los efectos de dosis progresivas 11 y 2 mg./Kg.l de duloxetina o clomipramina, administrados intravenosamente, sobre el tracto urinario inferior se estudiaron en un total de 32 conejos machos y 32 hembras, en condiciones normales (infundiendo continuamente suero salino en la vejiga) y mediante un modelo de irritación vesical (infusión continua de ácido acético al 0,5\% en la vejiga). Un catéter transuretral de doble lumen en machos, y una cistostomía subcutánea en hembras, se utilizaron para la infusión de líquido y para recoger la presión intravesical durante el cistometrograma. Simultaneamente, SAS-EMG fué registrada a través de dos electrodes situados en el músculo estriado perianal.

RESULTADOS: Parámetros cistométricos: En condiciones irritativas, clomipramina tras $2 \mathrm{mg} . / \mathrm{Kg}$. en los machos y de forma dosis-dependiente en las hembras, incrementó la capacidad vesical (CV), la duracion de la contracción (DC) y el intervalo entre contracciones (IC), y redujo la presión vesical (PB). Por otro lado, duloxetina incrementó la CV, la DC y el IC, de forma dosis-dependiente, tanto en conejos machos como en hembras, cuando fueron estudiados en condiciones irritativas. En condiciones normales, duloxetina, de forma dosisdependiente, y clomipramina, tras la administración de $2 \mathrm{mg}$./ Kg., sólo aumentaron la CV en los conejos hembra. Electromigrafía: Un potente efecto de duloxetina sobre la SAS-EMG, en condiciones de irritabilidad vesical, se vio tanto en machos como en hembras. En estas condiciones, la clomipramina incrementó, de forma dosis-dependiente, la SAS-EMG sólo en hembras. Por otro lado, en condiciones normales, el único efecto significativo sobre la SAS-EMG que se vio, fue con 2 $\mathrm{mg} . / \mathrm{Kg}$. de duloxetina en hembras.

CONCLUSIONES: Duloxetina produce un efecto marcado sobre la SAS-EMG en conejas en condiciones irritativas. En estas mismas condiciones, clomipramina tiene mayor efecto relajante sobre el detrusor, reduciendo la presión intravesical.

Palabras clave: Incontinencia urinaria. Clomipramina. Duloxetina. Tracto urinario inferior.

\section{INTRODUCTION}

Involuntary leakage of urine due to effort, exertion, sneezing or coughing is the most common type of urinary incontinence in women, with $78 \%$ of them presenting symptoms of stress urinary incontinence (SUI) in a pure $(49 \%)$ or mixed $(29 \%)$ form (1). Treatment for SUI is limited to pelvic floor muscle training, various types of devices, behavioral inter- ventions and surgery. Currently, there is no globallyapproved pharmaceutical treatment.

Pharmacological studies have implicated serotonin (5-hydroxytryptamine [5HT]) and norepinephrine (NE) systems in the neural control of lower urinary tract (LUT) function (2). In addition, bladder contraction occurs from acetylcholine stimulation of detrusor muscarinic receptors (3). Thus, the treatment of urinary incontinence could be done by drugs like antimuscarinic compounds, tricyclic antidepressants (TCAs) and combined $5 \mathrm{HT}$ and NE reuptake inhibitors (SNRIs), depending on the type of urinary incontinence.

Clomipramine belongs to the TCA family and is used to treat depression and obsessive-compulsive disorders, as it produces slight sedation in healthy and sick patients (4). The primary action mechanism of TCAs is to block 5HT and NE presynaptic neurotransmitter reuptake in the brain, reducing turnover and thus effectively increasing the action of these neurotransmitters. TCAs also have anticholinergic effects that traditionally account for several of their most common side effects. Clomipramine is distinguished from the other TCAs by its potent $5 \mathrm{HT}$ reuptake-inhibiting properties, which resemble those of the selective $5 \mathrm{HT}$ reuptake inhibitors such as fluoxetine $(4,5)$.

The class of SNRIs now comprises three medications: venlafaxine, milnacipran, and duloxetine. These drugs block the reuptake of both $5 \mathrm{HT}$ and NE with differing selectivity. Whereas milnacipran blocks $5 \mathrm{HT}$ and NE reuptake with equal affinity, duloxetine has a 10-fold selectivity for $5 \mathrm{HT}$ and venlafaxine a 30 -fold selectivity for $5 \mathrm{HT}(6)$. Duloxetine increases striated sphincter activity through central actions in the spinal cord, showing urine-storage-promoting effects $(2,7)$. It shows a weak or non-appreciable binding affinity for neurotransmitter receptors like muscarinics, histaminergics, $\alpha 1$-adrenergics, dopaminergics and opioids (8-10). The ability of duloxetine to stimulate pudendal motor neurons and increase striated sphincter contractility is the basis for its efficacy in women with SUI (11).

The storage-promoting effects are unique to dual reuptake inhibition in a single molecule and are not duplicated by the administration of 2 single-reuptake inhibitors (12). In the light of the compelling association between $5 \mathrm{HT}$ and NE systems and LUT function, clomipramine and duloxetine were examined in male and female rabbits to compare their effects on detrusor and striated sphincter function under both nonirritated bladder conditions (transvesical infusion of saline) and irritative conditions (i.e., transvesical infusion of $0.5 \%$ acetic acid). 
MATERIALS AND METHODS

Animals. A total of 32 male and 32 female New Zealand White rabbits weighing 2.5 to 3.5 $\mathrm{Kg}$. were separated into groups of 8 each and were studied infusing saline into the bladder to induce nonnoxious stimulation (nonirritative conditions) or under transvesical infusion of $0.5 \%$ acetic acid to induce noxious chemical stimulation (irritated bladder conditions) (2). The effects of intravenous 1 and $2 \mathrm{mg}$./ $\mathrm{Kg}$. duloxetine or clomipramine on cystometric and electromyographic parameters were studied in both nonirritative and irritative conditions. This study has been performed according to experimental protocols approved by Fundación Jiménez Díaz Institutional Animal Care and Use Committee.

Subcutaneous cystostomy. Female rabbits were studied through a subcutaneous cystostomy. After intramuscular injection of ketamine (Ketolar, Parke Davis, Barcelona, Spain, $25 \mathrm{mg} . / \mathrm{Kg}$.) and xylazine (Rompun, Bayer AG, Leverkusen, Germany, $10 \mathrm{mg} . / \mathrm{Kg}$.), the abdomen was opened by a lower midline incision and the bladder exposed. An $8 \mathrm{Fr}$ polyethylene catheter was inserted into the bladder dome and held in place with a purse-string suture. A multiperforable plug was placed at the end of the catheter. The catheter was tunnelled subcutaneously and anchored under the skin of the abdomen with a silk ligature (13).

Catheterization. In male rabbits, the bladder was catheterized through the urethra with an $8 \mathrm{~F}$ double-lumen catheter (AH5110, Porges, Barcelona, Spain) after the rabbit was anesthetized with halothane 2-3\% (Fluothane, Zeneca Farma, Pontevedra, Spain).

Cystometry. Continuous cystometry was performed with the animal supine and sedated with halothane $2-3 \%$, immediately after bladder catheterization in male rabbits, and 3 days after the surgical cystostomy in female rabbits. In the latter, a $T$ tube was connected to the multiperforable plug of the subcutaneous cystostomy using a 20-gauge needle, online with a TRA021 pressure transducer (Leti$\mathrm{ca}$, PanLab, Barcelona, Spain) and a micro injection pump (Razel 99, Scientific Instruments, Stamford, CT). A similar setting was also used in male rabbits through the double-lumen catheter. Room-temperature saline or diluted acetic acid was infused into the bladder at a rate of $1.4 \mathrm{ml} . / \mathrm{hr}$., to elicit repetitive voidings, which allowed collection of data for a large number of voiding cycles. Continuous cystometry was recorded on a PowerLab 4/25 (PanLab, Barcelona, Spain).
At the beginning of the cystometry the bladder was emptied. The liquid infusion to stabilize the cyclic voidings was maintained at least for 60 minutes, continuously recording the cystometrogram. Then, placebo was intravenously administered, and the cystometrogram was recorded for other 40 minutes. Finally, two consecutive doses of a drug, $1 \mathrm{mg} . / \mathrm{Kg}$. (low dose) and $2 \mathrm{mg} . / \mathrm{Kg}$. (high dose), were administered with an interval of 40 minutes. The cystometric parameters investigated were bladder capacity $(B C)$, baseline pressure (BP), contraction amplitude (CA), contraction duration $(C D)$ and intercontraction interval (ICI).

The doses of clomipramine and duloxetine selected were based on our pilot experiments and on previously-published data on their relative efficacy when given systemically.

Electromyography of striated anal sphincter (SAS-EMG). The anal sphincter was located based on anatomical landmarks, and two electrodes (30-gauge needle) were inserted into the striated anal sphincter (SAS) approximately $5-10 \mathrm{~mm}$. lateral to the anus. Electrical signals were amplified on an ML136 preamplifier (ADInstruments, PanLab, Barcelona, Spain), filtered below $1 \mathrm{~Hz}$ and above $5 \mathrm{kHz}$ and displayed on a PowerLab window. SAS-EMG was continuously recorded during the cystometry.
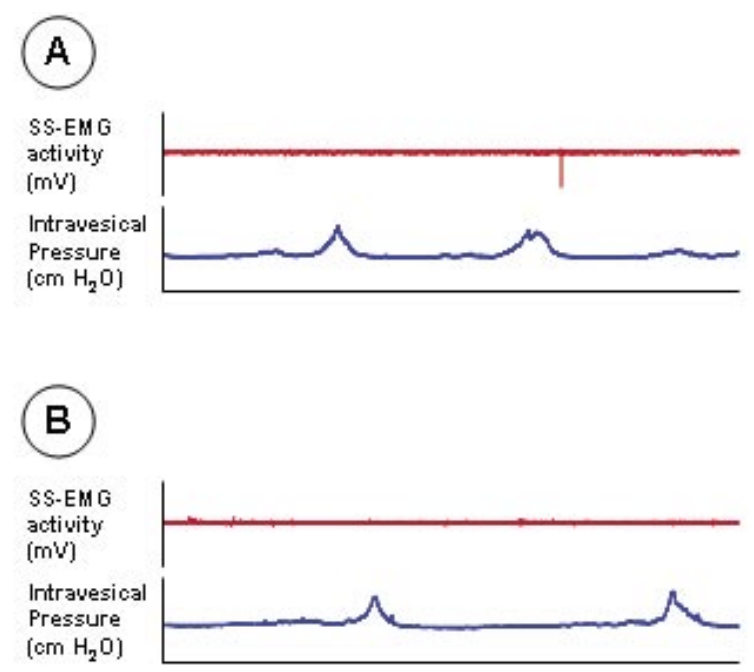

FIGURE 1. Representative examples of striated anal sphincter electromyography (SAS-EMG) and the associated cystometrogram (CMG) showing intravesical pressure in a female (A) and a male (B) rabbit during saline infusion into the bladder. Vertical bars equal $30 \mathrm{~cm}$. of water (for intravesical pressure) or $0.410 \pm 0.21 \mathrm{mV}$ (for SAS-EMG activity). Horizontal bars equal $15 \mathrm{~min}$. 
Drug administration. An intravenous cannula was connected to the ear vein for placebo $(1 \mathrm{ml}$. saline), clomipramine and duloxetine administration. The drugs were freshly prepared before each experiment in saline. Drugs were administered intravenously in a volume of $1 \mathrm{ml}$. followed by $1 \mathrm{ml}$. flush of physiological saline.

Statistical analysis. All values were expressed as the mean \pm SEM. Duloxetine and clomipramine effects were analyzed and compared using Wilcoxon rank test. Mann-Whitney $U$ test was performed to compare the values after placebo administration between irritative and nonirritative conditions, and to compare the effect of both duloxetine and clomipramine on SASEMG activity from male and female rabbits.

\section{A. Female}

\section{Acetic Acid Infusion}

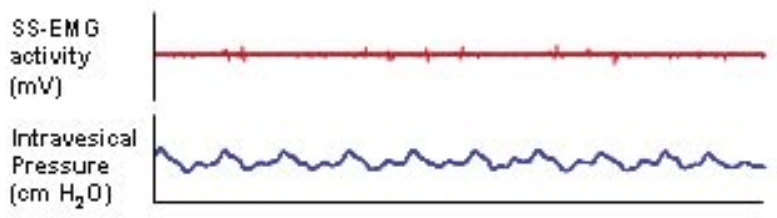

\section{Clomipramine (low dose)}

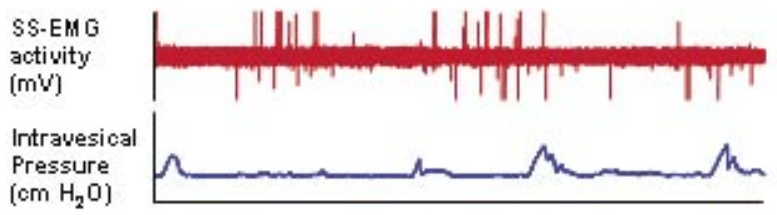

\section{Clomipramine (high dose)}

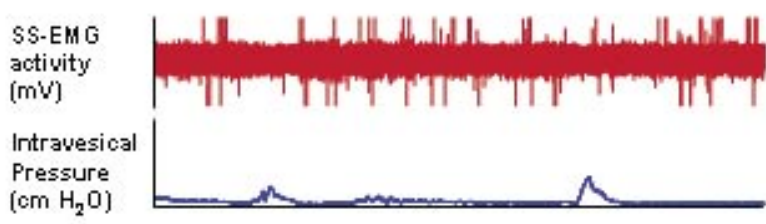

Cystometric and electromyographic parameters after placebo administration under nonirritative conditions were considered as "control". Statistical significance was considered at $p<0.05$.

\section{RESULTS}

Reproducible cystometric patterns were obtained (Figures 1-3). On switching to infusion of acetic acid, BC (p<0.05), CD ( $<<0.05)$ and $I C l(p<0.05)$ were reduced in male and female rabbits (Figures 4-6). Intravenous injection of placebo produced no effects on either cystometric parameters or SAS-EMG activity.

\section{B. Male}
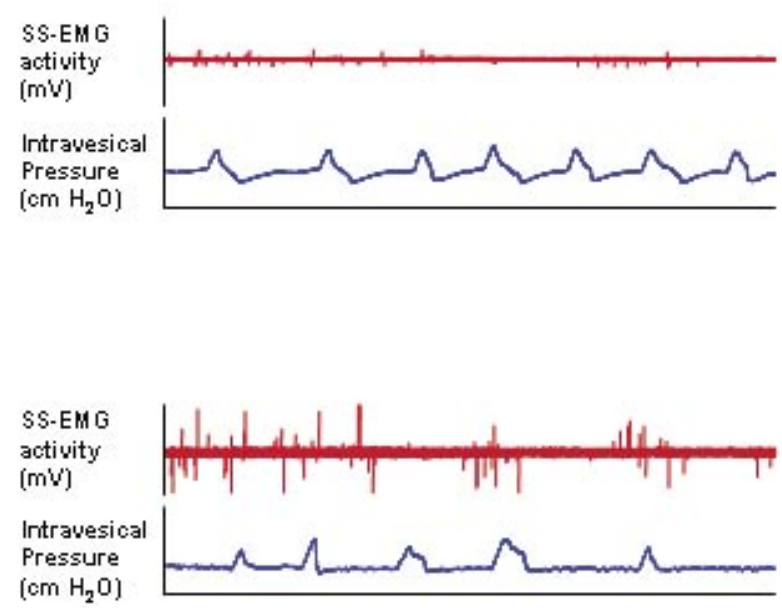

FIGURE 2. Examples from experiments showing the dose-dependent effects of clomipramine on the bladder pressure and the associated striated sphincter activity during infusion of $0.5 \%$ acetic acid into the bladder (CMG) in a female (A) and a male (B) rabbit. Vertical bars equal $30 \mathrm{~cm}$. of water (for bladder pressure) or $0.4(0 \pm 0.2) \mathrm{mV}$ (for SASEMG activity). Horizontal bars equal $15 \mathrm{~min}$. 


\section{A. Female}

\section{Acetic Acid Infusion}

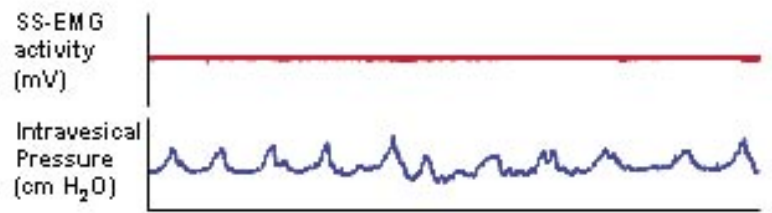

\section{Duloxetine (low dose)}

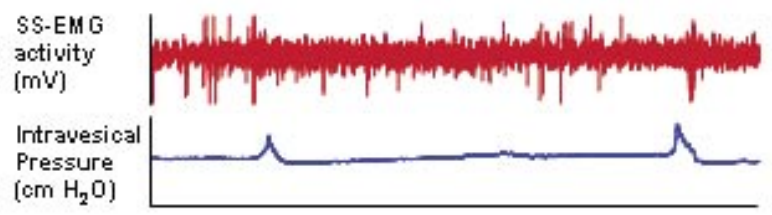

\section{Duloxetine (high dose)}

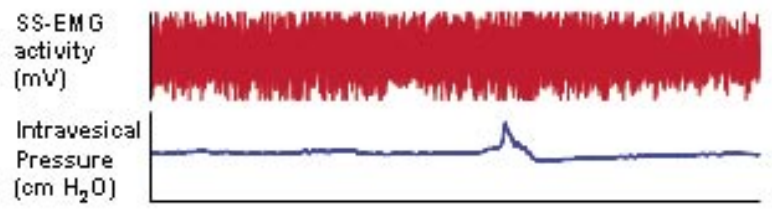

\section{B. Male}
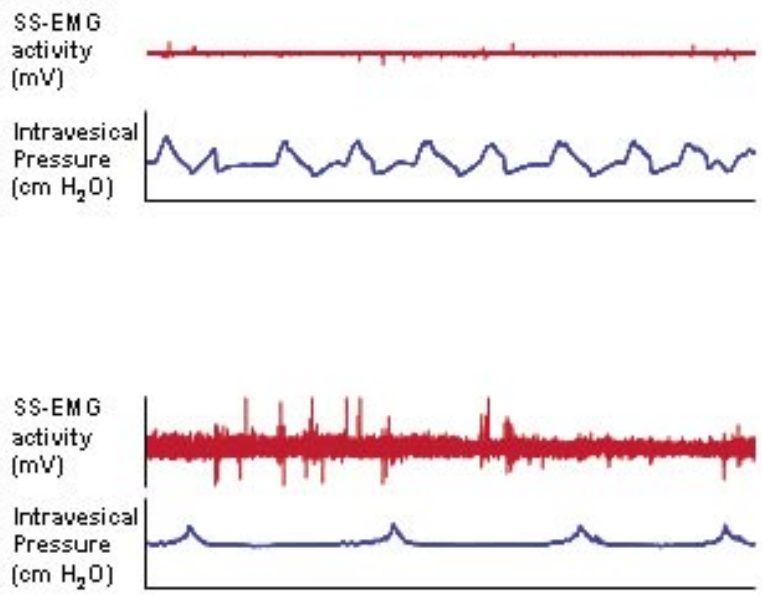

FIGURE 3. Examples from experiments in a female (A) and a male (B) rabbit showing dose-dependence of the effects of duloxetine on the bladder pressure (cm. of water) and the associated striated sphincter electromyographic activity during infusion of $0.5 \%$ acetic acid into the bladder. Vertical bars equal $30 \mathrm{~cm}$. of water (for bladder pressure) or $0.4(0 \pm 0.2) \mathrm{mV}$ (for SAS-EMG activity). Horizontal bars equal $15 \mathrm{~min}$.

Effects of clomipramine or duloxetine in male rabbits under acetic acid infusion into the bladder.

Clomipramine at high dose increased $\mathrm{BC}$ $(p<0.05), C D(p<0.05)$ and $\mathrm{ICl}(\mathrm{p}<0.05)$ (Figures 4$6)$ and decreased BP $(p<0.05)$ (Figure 7). Duloxetine increased dose-dependent $B C(p<0.05), C D(p<0.05)$ and $\mathrm{ICl}(\mathrm{p}<0.05)$ (Figures $4-6)$, the effects of duloxetine being greater than those of clomipramine. The administration of duloxetine or clomipramine produced no significant changes in the CA (Figure 8).

As regards SAS-EMG activity, duloxetine increased it dose-dependently $(p<0.05)$, but clomipramine had no significant effect on this parameter Figure 9).

The comparison of the effects of both drugs on $B C(p<0.05), C D(p<0.05), I C l(p<0.05)$ and
SAS-EMG activity $(p<0.05)$ shows that duloxetine has greater capacity to promote urine storage. On the other hand, clomipramine has a more relaxing effect on intravesical pressure $(p<0.05)$.

Effects of clomipramine or duloxetine administration in female rabbits under acetic acid infusion into the bladder.

Duloxetine and clomipramine increased dosedependent $B C(p<0.05), C D(p<0.05), I C I(p<0.05)$ and SAS-EMG activity $(p<0.05)$ (Figures $4-6,9)$. Clomipramine and duloxetine produced no significant changes in the CA (Figure 8). In addition, clomipramine also caused a decreased dose-dependence in $B P(p<0.05)$, whereas duloxetine caused no changes in BP (Figure 7). 
(A)

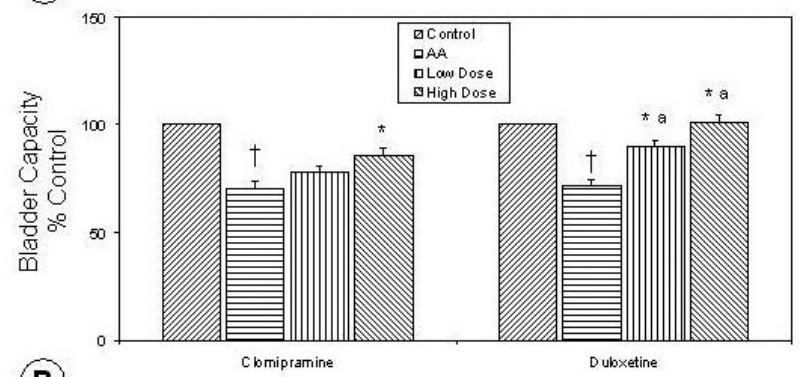

(B)

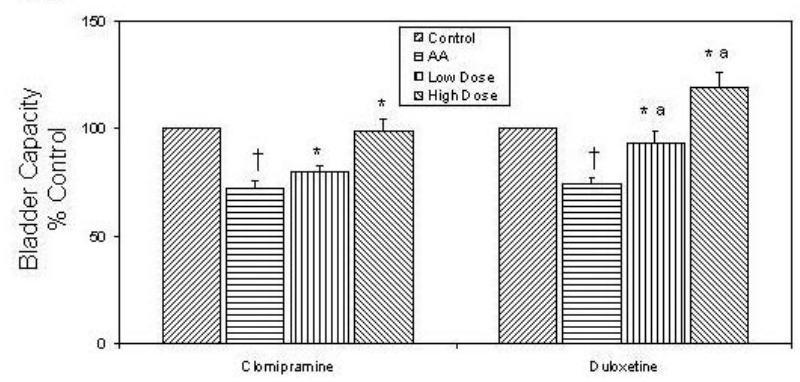

FIGURE 4. Comparative response to clomipramine and duloxetine in male (A) and female (B) rabbits. Bladder capacity after placebo administration under saline (controll) or acetic acid (AA) infusion, and after low and high dose administration of both clomipramine and duloxetine, under irritative conditions. Bars represent mean (\% Controll) \pm SEM of 8 rabbits each. *Indicates significantly different from AA ( $p<0.05)$ (Wilcoxon rank test). TIndicates significantly different from control values ( $p<0.05)$ (Mann-Whitney $U$ test). a Indicates significant differences vs clomipramine ( $p<0.05)$ (Wilcoxon rank test).

Cystometric parameters such as $B C(p<0.05)$, $C D(p<0.05)$ and ICI $(p<0.05)$, and SAS-EMG activity $(p<0.05)$ were significantly increased by duloxetine more than by clomipramine (Figures 4-6, 9).

Finally, the effect of duloxetine or clomipramine increasing dose-dependent SAS-EMG activity was higher in female rabbits, compared with male rabbits $(p<0.05)$ (Figure 9).

\section{Effects of clomipramine or duloxetine administration in male and female rabbits under saline infusion into the bladder.}

The effects that both clomipramine and duloxetine showed in cystometric and electromyographic parameters under nonirritated bladder condi-
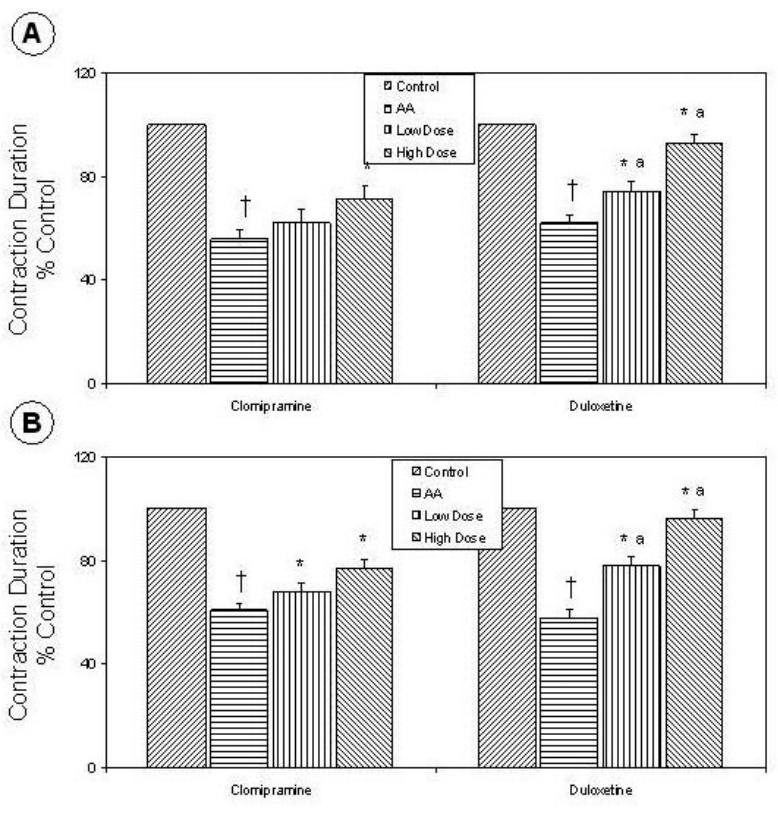

FIGURE 5. Comparative effect on contraction duration of cumulative doses of clomipramine or duloxetine in male (A) and female (B) rabbits. Bars represent mean (\% Controll) \pm SEM of 8 rabbits each, during nonirritative conditions (control), acetic acid infusion into the bladder (AA), and after administration of low and high doses of the respective drug, during transvesical acetic acid infusion. * Indicates significantly different from AA (p <0.05) (Wilcoxon rank test). tIndicates significantly different from control values ( $p<0.05)$ (Mann-Whitney $U$ test). andicates significant differences vs clomipramine ( $p<0.05)$ (Wilcoxon rank test).

tions were lower than in irritative conditions. Thus, clomipramine only increased $B C$ at high dose and in female rabbits. Duloxetine dose-dependently increased BC and, at high dose, increased SAS-EMG activity in female rabbits.

\section{DISCUSSION}

The results of the present study show that duloxetine and clomipramine increase BC and SASEMG activity under condition of acetic acid infusion into the bladder, the effects of duloxetine to promote urine storage were higher than those of clomipramine. Our findings suggest that duloxetine promotes urine storage by increasing outlet resistance, and clomipramine promotes urine storage both by relaxing the bladder and increasing outlet resistance. 
Duloxetine has been examined in vitro and in vivo, and it is a potent inhibitor of $5 \mathrm{HT}$ and NE reuptake, whereas it is a weak inhibitor of dopamine reuptake and the binding of radioligands to neurotransmitter receptors (8-10). It is assumed that its effects on cystometric parameters and SAS-EMG activity are mediated by increased extracellular $5 \mathrm{HT}$ and/or NE. It is thought clomipramine acts by this same mechanism, mainly through the inhibition of $5 \mathrm{HT}$ reuptake in the central nervous system (CNS) $(14,15)$, although it is unknown whether the effect on the LUT function is by anticholinergic mechanisms, as occurs in other organs (16).

Animal studies have implicated $5 \mathrm{HT}$ and NE in the neural control of LUT function. In cats, serotoninergic agonists suppress parasympathetic activity and enhance sympathetic and somatic activity, promoting urine storage by relaxing the bladder and increasing outlet resistance. NE variably affects the LUT depen-

(A)

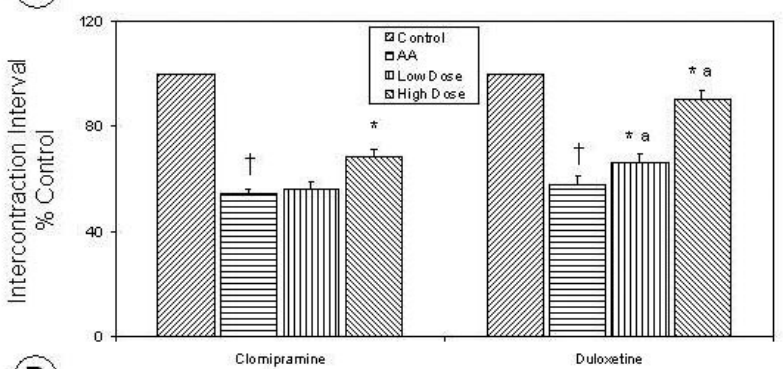

(B)

Clomipramine

Durosine

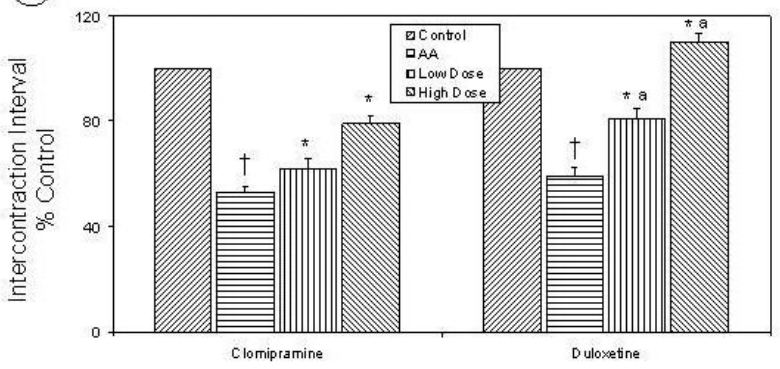

FIGURE 6. Comparative response to clomipramine and duloxetine in male (A) and female (B) rabbits. Intercontraction interval after placebo administration under saline (control) or acetic acid (AA) infusion, and after low and high dose administration of both clomipramine and duloxetine, under irritative conditions. Bars represent mean (\% Control) \pm SEM of 8 rabbits each. *Indicates significantly different from AA ( $p<0.05$ ) (Wilcoxon rank test). tIndicates significantly different from control values ( $p<0.05)$ (Mann-Whitney U test). andicates significant differences vs clomipramine ( $p<0.05)$ (Wilcoxon rank test). ding on the adrenergic receptor subtype with which it interacts (1).

There are some articles in which the inervation through the pudendal nerve of both urethral and anal striated sphincters (SUS and SAS, respectively) has been confirmed, as has the association between bladder, SUS and SAS (17-19). In addition, there are some articles in which both SUS- and SAS-EMG activity have been simultaneously studied, and the EMG recordings from the SAS were similar to those for the SUS (18-20). Thus, these previous results give convincing evidence to the use of SAS-EMG activity as an appropriate surrogate of the SUS-EMG activity.

Our findings are correlated with a previous study in cats in which duloxetine increased $B C$ and SAS-EMG activity through central actions in the spinal cord (2). Currently, Boy et al. (11) have also confirmed this hypothesis in a functional urodynamic
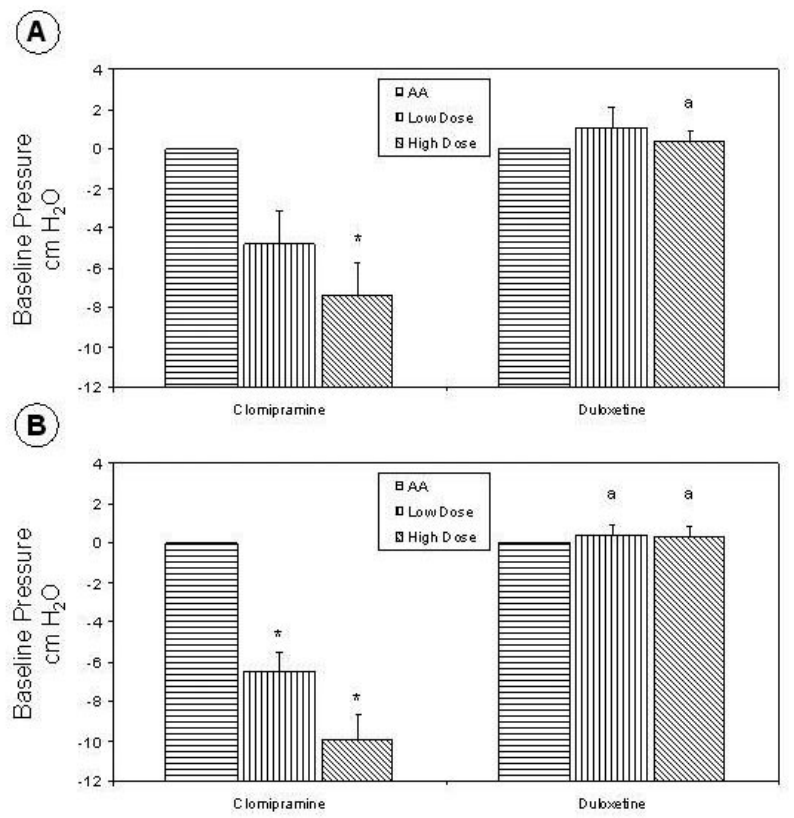

FIGURE 7. Comparative effect on baseline pressure of cumulative doses of clomipramine or duloxetine in male (A) and female (B) rabbits. Bars represent mean $(\mathrm{cm}$. of water) \pm SEM of 8 rabbits each, during irritative conditions (AA) after placebo administration (considered $O$ $\mathrm{cm}$. of water), and after administration of low and high doses of the respective drug, during transvesical acetic acid infusion. Baseline pressure after administration of placebo was considered $O$. * Indicates significantly different from $A A(p<0.05)$ (Wilcoxon rank test). aIndicates significant differences vs clomipramine $(p<0.05)$ (Wilcoxon rank test). 
experimental study in healthy women, in which it is confirmed that duloxetine has a significant effect on the excitability of pudendal motor neurons and on striated sphincter contractility, having a facilitatory neuromodulative effect on sphincter motor neurons in humans.

In this study, we have shown that clomipramine also promotes urine storage probably by the inhibition of 5HT and NE reuptake and by anticholinergic effects on LUT function. Among the various actions of TCAs on the peripheral and central nervous system, the cholinergic blockade of the post-junctional muscarinic receptors is responsible for most of the side-effects associated with clomipramine treatment $(16,21)$. However, it is known that the impairment caused by clomipramine treatment in the LUT is not paralleled by anticholinergic dysfunctions of other organs because, for example, it has a lower anticholinergic effect on LUT than in the heart (16).

(A)

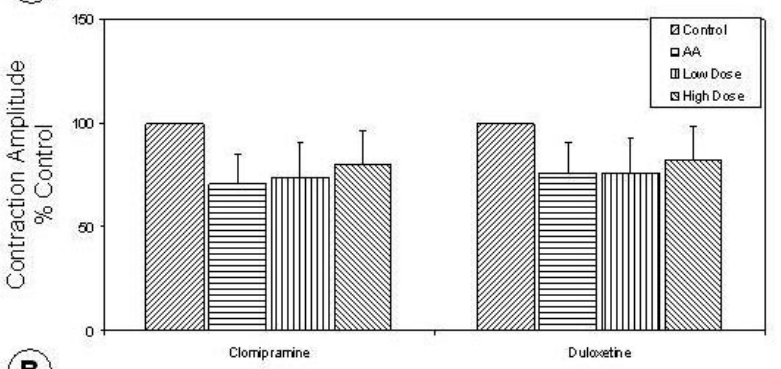

(B)

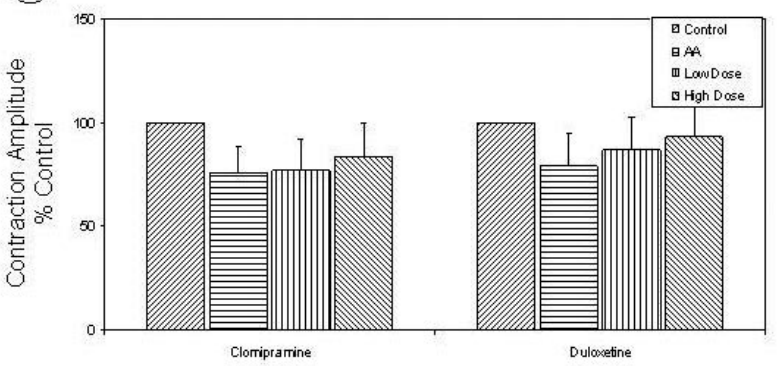

FIGURE 8. Comparative response to clomipramine and duloxetine in male (A) and female (B) rabbits. Contraction amplitude after placebo administration under saline (control) or acetic acid (AA) infusion, and after low and high dose administration of either clomipramine or duloxetine, under irritative conditions. Bars represent mean (\% Control) \pm SEM of 8 rabbits each.
There are contradictory studies about the anticholinergic effect of clomipramine in the LUT $(15,16,21)$, which is principally based on its effect on other organ functions (16). Signs of parasympathetic denervation on LUT has been attributed to clomiramine in a study of Kristensen, E. et al. (16) in human volunteers and in another work of Pfeiffer, E. et al. (21) in a cat, whereas the episodes of urinary retention in an adolescent, caused by clomipramine treatment, did not respond to bethanechol (activating muscarinic receptors), nor to phenoxybenzamine (blocking cervico-urethral adrenergic receptors). Thus, a possible involvement of non-cholinergic, non-adrenergic (NANC) mechanisms in this adverse reaction to clomipramine was suggested $(5,15)$.

Our present data support that duloxetine's effects are higher under conditions that activate bladder nociceptive primary afferent fibres (under transvesical $0.5 \%$ acetic acid infusion), also sugges-
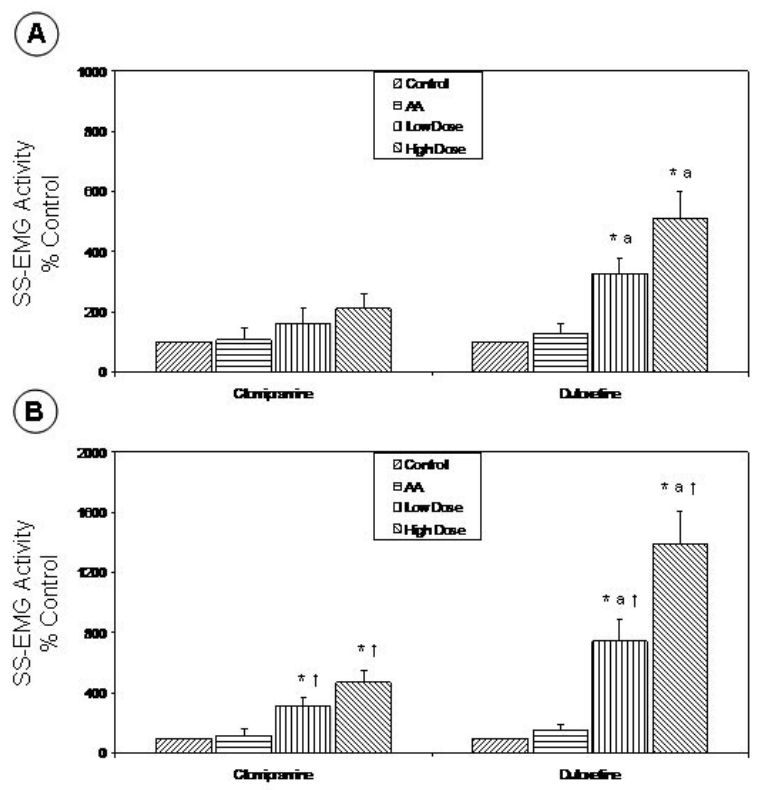

FIGURE 9. Comparative effect on SAS-EMG activity of cumulative doses of clomipramine or duloxetine in male (A) and female (B) rabbits. Bars represent mean (\% Control) \pm SEM of 8 rabbits each, during saline (control) or acetic acid (AA) infusion into the bladder after administration of placebo, and after low and high dose administration of the respective drug, during transvesical acetic acid infusion. *Indicates significantly different from AA ( $p<0.05$ ) (Wilcoxon rank test). $\uparrow / n d i-$ cates significantly different from male rabbits $(p<0.05)$ (Mann-Whitney $U$ test). alndicates significant differences vs clomipramine ( $p<0.05)$ (Wilcoxon rank test). 
ting that duloxetine affects sensory processing, specifically nociceptive bladder afferent pathways in rabbits, as was described previously in cats (2).

We have demonstrated that either duloxetine or clomipramine can be more effective promoting urine storage in female than in male rabbits, principally because of their higher effect on SAS-EMG activity in the former. Another hypothesis for these higher results in females is that the levels of $5 \mathrm{HT}$ in the human brain are substantially lower in females than in males (22), although it could mainly explain the difference in the effects of clomipramine because of its potent $5 \mathrm{HT}$ reuptake-inhibiting properties.

In addition, duloxetine has a significant effect on LUT in male rabbits, as has been shown in a preliminary work in men, in which it was suggested that duloxetine is effective in men with SUl after prostatectomy or cystectomy (23).

\section{CONCLUSION}

The present study has shown that clomipramine and duloxetine administration increases cystometric parameters and SAS-EMG activity in irritative conditions. Because these effects would promote urine storage, our findings support that $5 \mathrm{HT}$ and $\mathrm{NE}$ systems are intimately involved in maintaining continence in the rabbit. The effects seen after duloxetine administration are higher compared with those after clomipramine administration. Thus, whereas the former acts principally by increasing outlet resistance, clomipramine acts either by increasing outlet resistance or directly relaxing the detrusor.

\section{ACKNOWLEDGEMENTS}

We thank J. de la Cruz, M.L. Valbuena and C. Carnero for animal care, P. Manzano for technical assistance, and Dr. J.J. Granizo for assistance in statistical analysis. F.C.P.M. is a fellow of Fundación Conchita Rábago.

This work was supported in part by Fundación de Investigación en Urología (Asociación Española de Urología).

\section{REFERENCES AND RECOMENDED READINGS (*of special interest, "* of outstanding interest)}

**1. DMOCHOWSKI, R.R.; MIKLOS, J.R.; NORTON, P.A. et al.: "Duloxetine versus placebo for the treatment of North American women with stress urinary incontinence”. J. Urol., 170: 1259, 2003.

**2. THOR, K.B.; KATOFIASC, M.A.: "Effects of duloxetine, a combined serotonin and norepinephrine reuptake inhibitor, on central neural control of lower urinary tract function in the chloralose-anesthetized female". Cat. J. Pharmacol. Exp. Ther., 274: 1014, 1995.

3. RUGGIERI, M.R.; BRAVERMAN, A.S.; PONTARI, M.A.: "Combined use of [alpha]-adrenergic and muscarinic antagonists for the treatment of voiding dysfunction”. J. Urol., 174: 1743, 2005.

4. BALDESSARINI, R.J.: "Drugs and treatment of psychiatric disorders". Hardman, J.E.; Limbird, L.E.; Molinoff, P.B.; Ruddon, R.W.: The Pharmacological Basis of Therapeutics, 431-460, McGraw Hill, New York, 1996.

5. LEE, K.S.; NA, Y.G.; DEAN-McKINNEY, T. et al.: "Alterations in voiding frequency and cystometry in the clomipramine-induced model of endogenous depression and reversal with fluoxetine". J. Urol., 170: 2067, 2003.

6. STAHL, S.M.; GRADY, M.M.; MORET, C. et al.: "SNRIs: their pharmacology, clinical efficacy and tolerability in comparison with other classes of antidepressants". C.N.S. Spectr., 10: 732, 2005.

7. VELA NAVARRETE, R.; PÉREZ MARTÍNEZ, F.C.; CABRERA PÉREZ, J. et al.: "Duloxetina y otros antidepresivos tricíclicos: efectos farmacodinámicos en el tracto urinario inferior". Actas. Urol. Esp., 27: 751, 2003.

8. WONG, D.T.; BYMASTER, F.P.; MAYLE, D.A. et al.: "LY248686, a new inhibitor of serotonin and norepinephrine uptake". Neuropsychopharmacol., 8: 23, 1993.

9. FULLER, R.W.; HEMRICK-LUECKE, S.K.; SNODDY, H.D.: "Effects of duloxetine, an antidepressant drug candidate, on concentrations of monoamines and their metabolites in rats and mice". J. Pharmacol. Exp. Ther., 269: 132, 1994.

10. LANTZ, R.J.; GILLESPIE, T.A.; RASH, T.J. et al.: "Metabolism, excretion, and pharmacokinetics of duloxetine in healthy human subjects". Drug. Metab. Dispos., 31: 1142, 2003.

11. BOY, S.; REITZ, A.; WIRTH, B. et al.: "Facilitatory Neuromodulative Effect of Duloxetine on Pudendal Motor Neurons Controlling the Urethral Pressure: A Functional Urodynamic Study in Healthy Women”. Eur. Urol., 50: 119, 2006. 
12. KATOFIASC, M.A.; NISSEN, J.; AUDIA, J.E. et al.: "Comparison of the effects of serotonin-selective, norepinephrine-selective and dual serotonin and norepinephrine reuptake inhibitors on lower urinary tract function in cats". Life Sci., 71: 1227, 2002.

*13. VELA NAVARRETE, R.; PÉREZ MARTÍNEZ, F.C.; CASTILLA REPARAZ, C. el al.: "Experimental methods for "in vivo" study of detrusosphincteric pharmacological response: A critical review". Arch. Esp. Urol., 57: 461, 2004.

14. LEVIN, R.M.; WEIN, A.J.: "Comparative effects of five tricyclic compounds on the rabbit urinary bladder". Neurourol. Urodyn., 3: 127, 1984.

15. HERMESH, H.; AIZENBERG, D.; WEIZMAN, A. et al.: "Clomipramine-induced urinary dysfunction in an obsessive-compulsive adolescent". Drug Intell. Clin. Pharm., 21: 877, 1987.

16. KRISTENSEN, E.; JAKOBSEN, J.; BARTELS, U. et al.: "Cholinergic dysfunction of heart, pupil, salivary glands and urinary bladder in healthy volunteers during long-term treatment with clomipramine". Psychopharmacol., 98: 398, 1989.

17. WENZEL, B.J.; BOGGS, J.W.; GUSTAFSON, K.J. et al.: "Detection of neurogenic detrusor contractions from the activity of the external anal sphincter in cat and human". Neurourol. Urodyn., 25: 140, 2006.

18. THOR, K.B.; MUHLHAUSER, M.A.: "Vesicoanal, urethroanal, and urethrovesical reflexes initiated by lower urinary tract irritation in the rat". Am. J. Physiol., 277: R1002, 1999.

19. KERNS, J.M.; SHOTT, S.; BRUBAKER, L. et al.: "Effects of IGF-I gene therapy on the injured rat pudendal nerve. Int. Urogynecol". J. Pelvic Floor Dysfunct., 14: 2, 2003.

20. THOR, K.B.; MUHLHAUSER, M.A.; SAUERBERG, P. et al.: "Central muscarinic inhibition of lower urinary tract nociception". Brain Res., 870: $126,2000$.

21. PFEIFFER, E.; GUY, N.; CRIBB, A.: "Clomipramine-induced urinary retention in a cat". Can. Vet. J., 40: 265, 1999.

22. NISHIZAWA, S.; BENKELFAT, C.; YOUNG, S.N. et al.: "Differences between males and females in rates of serotonin synthesis in human brain". Proc. Natl. Acad. Sci. U.S.A., 94: 5308, 1997.

23. SCHLENKER, B.; GRATZKE, C.; REICH, O. et al.: "Preliminary results on the off-label use of duloxetine for the treatment of stress incontinence after radical prostatectomy or cystectomy". Eur. Urol., 49: 1075, 2006. 